\title{
Nous and Aisthēsis: Two Cognitive Faculties in Aristotle
}

\author{
Adriana Renero \\ The Graduate Center, City University of New York \\ arenero@gc.cuny.edu
}

At the beginning of Book VI of the Nicomachean Ethics (NE) Aristotle makes a crucial point: the cognitive faculties are defined in terms of their objects, i.e., "by being somehow similar and appropriate to their objects" (1139a11-12). ${ }^{1}$ One may question how it is that nous (intelligence) $^{2}$ is able to grasp two different objects: particulars and universals. ${ }^{3}$ Since Aristotle explicitly distinguishes between particulars and universals, one may wonder how both of these two actually are objects of the same cognitive faculty, and how two different processes, i.e., demonstration for universals and perception for particulars, operate here. Aristotle seems to suggest that nous can be considered a sort of perception (aisthēsis) that, starting from particulars, proceeds by induction (1142a28-9; 1143b5-6). Does Aristotle's suggestion equate nous and aisthēsis in some sense?

Understanding the relation between nous and perception is a very important and controversial aspect of Aristotle's $N E$ that requires examination. The objective of this paper is to undertake such an examination. The first problem to solve is determining whether nous and aisthēsis are concerned with the same objects or not. If we take into account Aristotle's claim that a cognitive faculty is defined in terms of its objects, the answer must be negative.

Claudia Baracchi's recent major work (2008) argues for a controversial thesis; she argues that there is a "simultaneity and indissolubility, if not identity," of nous and aisthēsis at the core of Aristotle's philosophy which "entail[s] the most far-reaching consequences" (pp. 20; 193204). Focusing on a key passage in VI.11, (1143a33-b14), Baracchi reaches outside of the NE to support her interpretation of it. She claims that in Metaphysics (Met) A.1, Aristotle provides a hint about "the genealogy of a noetic perception" (nous) (p. 23). According to Baracchi, Aristotle expands on this notion especially in Posterior Analytics (AnPo) B.19 where he intimates "the indissoluble concomitance (if not the sameness) of nous and aisthēsis;" Aristotle considers "aisthēsis as informed by nous and deepens his examination of the structure of the intertwinement of the two" (p. 28). ${ }^{4}$

\footnotetext{
${ }^{1}$ Unless I indicate otherwise, I follow Irwin's translation (1999) for NE, Barnes' (1975) for Posterior Analytics, Ross' (1995) for Metaphysics, and Irwin's (1995) for De Anima.

${ }^{2}$ Nous is traditionally translated as 'understanding,' 'intellectual intuition, 'and merely 'intuition.' I use 'intelligence' as Rowe (2002).

${ }^{3}$ The universal is conceived as (a) 'katholou' i.e., 'taken as a whole' or in general, as opposed to 'taken each in turn' or particular; (b) that which can be or must be predicated of many things; (c) the primary object of definition, and scientific-knowledge. Cf. Irwin \& Fine, 1995, p. 619.

${ }^{4}$ Baracchi translates aisthesis as 'sensibility,' 'sensible-perception,' and 'sensation.' She recognizes that nous is translated as 'intellect' or 'intuition.' Since she equates nous and aisthesis, then nous is considered as 'sensible-intuitive,' 'noetic-perception,' 'intuitive-perception,' and 'intellectual-perception' without distinction (pp. 16-52).
} 
Unquestionably, there are important parallels in the discussions of NE VI.8 and 11, Met A.1, and AnPo B.19. ${ }^{5}$ The AnPo generates questions about the nature and cognitive status of epistēme and nous, which are regarded as always true. The discussion seems to suggest that nous possesses a higher epistemic status than epistēme because the former grasps first principles (archai), while the latter is the grasp of what follows from them. ${ }^{6}$ On the other hand, B.19 seems to say that perception and experience are necessary conditions for obtaining nous, and so epistème, in the first place. ${ }^{7}$ Nonetheless, even if Aristotle grants a higher status to nous than to episteme $\bar{e}$, and perception is ultimately the source of nous and all knowledge, to suggest as does Baracchi that there is an "indissolubility' of nous and aisthēsis is a large and questionable step.

Moreover, it is doubtful that consideration of the Met and AnPo would justify such a strong view. While I do not have the space to discuss the Met and AnPo, I can say that Baracchi's general reading is accurate. It is her specific view about the aforementioned relation of nous and aisthessis that is unorthodox and too extreme.

My goal here is to examine critically Baracchi's view in light of a close reading of two central and complex passages VI.8, 1142a12-30 and VI.11, 1143a33-b12 from the $N E$ to show that her view is unpersuasive. I argue that Aristotle here maintains a fundamental distinction between nous and aisthēsis. He considers nous to be a different capacity than sensation and mere perception, and one through which particulars and indemonstrable principles become intelligible. I show further the significance of Aristotle's claim that a state is defined in terms of its objects for understanding the distinction between nous and aisthēsis.

This paper has three main sections: in the first, I will present a detailed overview of Baracchi's argument in order to raise general problems with her account and to show that it conflicts with Aristotle's overall project. In the second, I will examine the first central passage, which sets up key issues for the second passage. In the last section, I analyze the second passage, which will reveal more specific problems with Baracchi's reading.

\footnotetext{
${ }^{5}$ Baracchi suggests that $A n P o$, Met, and $N E$ are "dynamically related and forming an organic whole" (p.
} 13).

${ }^{6}$ Barnes (1975) translates nous as 'comprehension' and epistēmē as 'understanding.' Understanding "requires knowledge of the explanation and of what cannot be otherwise" (p. 83, see also p. 97).

I use 'scientific-knowledge' for epistēmē as Irwin (1999), and as regarded in the relevant passages of our discussion, i.e., NE VI.8, VI.11 and AnPo B.19. So I intentionally omit discussion on AnPo A.2 and A.3.

Although I do not address the discussion about different characterizations of 'episteme'e' in $A n P o$, it is important to observe that at B.19 Aristotle connects epistēme to demonstration, and distinguishes between nous and episteme (see also Barnes, p. 98) - this is the sense that I tackle in this paper. Nonetheless, it is necessary to keep in mind that "Aristotle's terminology is not stable": at A.2, Aristotle says: "we do know through demonstration" i.e., scientific deduction "and by scientific [epistemonikos] I mean one in virtue of which, by having it, we understand [epistasthai] something" (71b16-19). Moreover, "apprehension of the principles is classed as a sort of understanding [epistēmēe" (Barnes, p. 98); therefore, nous — which grasps principles (at B.19)—can be considered a sort of epistēme (at A.2).

On the other hand, at A.3, Aristotle says: "the account of understanding threatens a regress which leads either to skepticism (72b7) or to the admission of circular proof (72b18); but in fact there is non-demonstrative understanding of the principles (72b18[-20])" (Barnes, p. 83; see also 84-98). Hence, epistēmé can be considered a genus term, which involves both demonstration and nous. In other words, in these contexts, nous would be a sort of epistēmē.

See Perelmuter (2010) for another interpretation on the distinction between nous and non-demonstrative knowledge, and for the objects of nous: terms or concepts (horoi) vs. propositions or definitions: the objects of nondemonstrable epistēmē, pp. 228-254.

${ }^{7}$ See also $N E$ 1141b18-20, 1142a14-21, and 1143a37-b12. 


\section{Baracchi's Project}

In Aristotle's Ethics as First Philosophy (2008) Claudia Baracchi's general project is to show that Aristotle believes that ethics is ontologically prior to metaphysics (and epistemology).

She offers an iconoclastic reading of Aristotle's discussion of the virtues of thought based on the supposition that practical wisdom (phronēsis) is theoretical in nature. ${ }^{8}$ She maintains that both phronēsis and theoretical wisdom (sophia) have as their object and end 'the highest good,' which, she asserts, is the first of all principles. Baracchi's reading is erected against traditional views that establish a hierarchy that favors the practical sphere over the theoretical, or vice versa. However, she challenges Aristotle's explicit distinction between phronēsis and sophia by attributing an "inseparability" or "indissoluble intertwinement" of these virtues, which is supposedly at the core of Aristotle's philosophy (pp. 1, 172, 213-4; cf. 170-219). In arguing for such an intertwinement, Baracchi alludes to a concomitance of praxis and theōria and claims that sophia is not only theoretical or contemplative but "inherently practical," given that it is "simultaneously" involved with "sensibility, experience, and, hence action". Phronēsis is also "pervasively theoretical" given that, in addition to the agent's actions, it contemplates the good for oneself and the others (pp. 210-4; cf. 123; 208).

It is worthwhile to see that although Baracchi offers a reading of passage VI.11, 1143a33b14 (see §III), she omits the last sentence where Aristotle concludes by establishing an explicit difference between phronessis and sophia. It is not surprising why Baracchi overlooks this line. However, this point works as evidence against her view that phronēsis and sophia are inseparable. Certainly, phronēsis and sophia may share some properties, e.g., both aim at the truth, and the agent that possesses phronesis, the phronimos, can be potentially sophos and may achieve 'the highest good' (eudaimonia) in the activity of contemplation (NE X.7-8). However, Aristotle explicitly distinguishes phronēsis and sophia in terms of their nature, contents, methods of knowing and grasping the truth, as well as their agents' function (ergon), ends (télos) and motivations (NE VI.8-11, X).

What is at stake here is that Baracchi's general reading seems to resemble her interpretation of some parts of VI.11, where she unjustifiably imposes the same notion of an "inseparability" of nous and aisthēsis. She may attempt to show that there is also no hierarchy between these two cognitive faculties; however, it seems implausible within Aristotle's larger project. Throughout the discussion, she uses interchangeably adjectives such as, 'identity,' 'sameness,' 'conjunction,' 'unity,' 'indissolubility,' 'inseparability,' 'coincidence,' 'intertwinement,' and 'indissoluble concomitance' to refer to the relation between these two cognitive faculties. ${ }^{9}$ Presumably, this relation is justified in AnPo B.19 and NE VI.11 by (A) the

${ }^{8}$ Note the contrast with Reeve (2006; 1992): (1) phronēsis is supplemented by theoretical wisdom (sophia), or (2) epistēmē is a necessary condition in order for phronēsis to grasp certain kind of objects. Such dependency can be seen: (1) "phronēsis as theoretical wisdom's steward" or (2) phronēsis as requiring epistēmē. Reeve (2006) restricts the sphere of phronēsis to particular premises. Since phronēsis consists more in perception than in knowledge of universals, "it gains its knowledge of them at second hand from the scientific part" (pp. 10-11).

On a reconciliation of the practical and contemplative spheres, see Rorty (1980), "The place of contemplation in Aristotle's Nicomachean Ethics" pp. 377-394.

${ }^{9}$ Baracchi suggests an identity but she does not commit to this claim throughout; her theses vary from weaker to more restrictive. 
role that sensation and induction play in grasping first principles, ${ }^{10}$ and (B) the fact that nous proceeds without logos to grasp its objects. ${ }^{11}$

These issues generate important results for epistèmé: since epistēmē needs nous because it is able to grasp non-demonstrable principles without logos, and since the premises of epistēmē begin from sensation through an inductive process, and experience is relevant for acquiring epistème, it follows - according to Baracchi-that there is a limit of epistemēe: "a certain secondariness and non-self-sufficiency of the sciences." Therefore, epistēmē needs to be "reinscribed" "within the context of sensibility, intuitive-inductive evidence, and [...] the experiential and practical domain" (pp. 189; cf. 187-195, 204, 213). ${ }^{12}$

It is important to see that Baracchi correctly understands Aristotle's account of how first principles can be known, and the cognitive faculty by means of which it is possible to know them. ${ }^{13}$ She observes that Aristotle recognizes the necessity of aisthēsis and experience for scientific-knowledge. Since first principles are non-demonstrable, they cannot be grasped deductively through epistemé; therefore, they must be grasped inductively. The state by which it is possible to apprehend the principles is nous (cf. AnPo B.19, see my fn. 6 for clarification).

Notwithstanding the core of her view remains unpersuasive. I focus on two main problems. The first concerns her attribution of a 'simultaneity and indissolubility' or the possibility of an identity of aisthēsis and nous. Is she simply claiming that aisthessis and nous operate together? Does she go further by maintaining that these states are identical or only that even though they are different are to be considered the same? It is unclear what sort of relation she attributes to Aristotle.

A simple identity refers to two statements that assert that a named individual is identical to another named individual. If she considers a simple identity here, then, nous = aisthessis. That is, we assume that nous is the same thing as aisthesis or that nous and aisthēsis designate the same cognitive faculty. It might be that Baracchi uses 'simultaneity and indissolubility' of nous and aisthēsis as a 'conjunction' or rule of implication, which stands for the claim that two propositions, say, $N$ and $A$, asserted separately may be conjoined in whatever order either $N$ and $A$, or $A$ and $N$, without appeal to the commutative rule for conjunction. So Baracchi may posit that nous implies aisthēsis and that aisthēsis implies nous. It is unclear, however, how these cognitive faculties are implicated in the grasp of their respective objects.

Baracchi's inconsistent usage of terms to refer to those relations without offering further explanation, leads us to suspect that she may hold a less restricted relation. For instance, 'coincidence' and 'concomitance' seem to involve such a relation. However, in order to

\footnotetext{
${ }^{10}$ Baracchi says: we come to know universals and first principles thanks to sensation. Since "sensation is of the universal, it literally produces the universal in us." "Indeed, sensation brings... the possibility of revealing and actualizing the capacity ... of nous." Hence, "[t]he formation and apprehension of universals is illuminated as a simultaneity and indissolubility, if not identity, of sensibility (aisthēsis) and intellectual perception (noēsis)" (pp. 35, $32,20)$.

${ }^{11}$ Baracchi says: Nous grasps first principles without logos: "qua principles" they are inductively achieved "from sensibility." Although principles "differ from particulars and cannot be reduced to them..., their genealogy... prevents us from thinking that universals and particulars are separable... or even opposed." Hence, "the ground for universal-apodictic procedures is the particular, which requires sensation and experience. Such is the arkhe of epistēme $\vec{e}$ (pp. 191-2, 187-8).

${ }^{12}$ One might think that by subordinating the role of epistēme, Baracchi also undermines her general project. Directly opposed to Baracchi's view, Reeve $(1992 ; 2006)$ attempts to strengthen the role of epistēme and to subordinate the role of aisthēsis and phronēsis.

${ }^{13}$ Irwin (1999) differentiates between 'to know' as gignōsk ein: grasping, or to be acquainted with something, and epistēmē or scientific-knowledge (p. 241). Here I use 'knowledge' with the former connotation.
} 
maintain this, it is necessary that a statement shows that there are $n$ satisfied conditions that state $N$ shares with state $A$, in comparison to another state that does not share $n$ conditions. Since she does not present these conditions, it is questionable that nous and aisthēsis correspond in such a sense.

Moreover, it is unclear whether 'nous 'and 'aisthēsis,' when Baracchi uses them independently, refer to such a relation or not. For example, when she seems to imply that the particular or sensation is the archē of epistēmē, we do not know if she also implies that nous is. At AnPo 88b36-7 and 100b15-6 Aristotle states that nous is the principle of epistemē. However, if 'sensation' is conceived of as 'identical' to nous, then, she means that sensation and nous 'simultaneously' are the archē of epistèmé. In the framework of this problem, we face another difficulty: Aristotle considers that nous has a higher epistemic status over epistēme, but not sensation or nous with the connotation of being 'inseparable' to sensation. Consequently, it is unlikely that there is a prevalence of sensation over epistēmē or "a certain secondariness of the sciences," as Baracchi supposes.

The second problem with Baracchi's reading concerns her attribution of a necessary "reinscription" of epistēme within the practical order. While perception and experience are surely sources of episteme $\bar{e}$, Aristotle stipulates that this state is independent of the practical sphere (NE 1140b1; 1141b10; 1142a25-8; 1142b1-3). The objects of epistēmē and phronēsis are fundamentally different from one another as well as from those that mere perception grasps (see $\S$ II).

With this preliminary view explained, we shall see that these problems come to fore in the analysis of our second central passage: VI.11, 1143a33-b12 where I contend with Baracchi's reading of relevant parts. As the important concepts are clarified in the following section, we are able to avoid the seemingly inescapable "indissolubility" between nous and aisthēsis that Baracchi asserts. The consequence of these elucidations would bring about a better understanding of the nature of nous. I will next go into examining Aristotle's passages.

\section{Aristotle's NE: the Account of Nous and Aisthēsis}

Passages VI.8, 1142a12-30 and VI.11, 1143a33-b12 have several connections with other passages from Book VI; however, scholars have agreed that these two are directly connected to each other.

Overall Book VI contains Aristotle's discussion of the virtues of thought. He explains that the rational part of the soul is divided in two: the deliberative or "rationally calculating" part (logistikon) and the "scientific part" (epistemonikon) (1139a13-14). Further, these "parts possess knowledge [or a certain sort of cognition] by being somehow similar and appropriate to their objects" (1139a11-12). The "scientific part" studies universals or necessary beings that are the objects of the natural sciences or physics, and mathematics, whereas the "rationally calculating" part is concerned with particulars, i.e., variable or contingent things (1139a7-9; cf. 1139b23-24; $1140 \mathrm{~b} 30-35 ; 1141 \mathrm{a} 23-27)$. The latter, then, is concerned neither with necessity (anankē) nor demonstration (apodeixis).

Aristotle says in addition that the "best state" (hexis) of these parts "is the virtue of each of them" and that the virtue "is relative to its own proper function" (ergon) (1139a16-18). ${ }^{14}$

\footnotetext{
${ }^{14}$ Hexis is traditionally translated as 'to have' and 'be disposed in some way;' a relatively permanent way a subject is disposed (cf. Irwin \& Fine, 1995, p. 615).
} 
Hence, the virtuous states of the theoretical and rationally calculating parts are called, respectively, scientific-knowledge (epistēmē) and practical wisdom (phronēsis). We should keep in mind that Aristotle specifies this distinction in our first central passage (1142a12-30).

Now if the objects known by phronēsis and epistēmē differ in kind, but entail a certain kinship with them, it should follow that even if phronēsis involves possessing a certain sort of knowledge of 'universals,' it is not the same state as epistèmé. Rather, there should be a certain kind of 'universals' that is suitable for practical wisdom.

In order to explain the nature of these states, Aristotle frequently analyzes them based on the premise that the nature of the cognition is defined in terms of the objects that it grasps. In other words, the "cognitive faculties must resemble their objects in order to cognize them" (Broadie, 2002, p. 361). This point is recurrent throughout the discussion of Book VI-notice in these passages how the differentiation among cognitive faculties is given as a function of their objects of apprehension.

\section{A. NE: VI.8, 1142a12-30}

I turn now to the first central passage: ${ }^{15}$

[A] A sign of what has been said about the unclarity of what [phronēsis] requires [A'] is the fact that whereas young people become accomplished in geometry and mathematics, and wise within these limits, [practically wise] young people do not seem to be found. [A"] The reason is that [phronessis] is concerned with particulars as well as universals, and particulars become known by experience [empeiria], [B] but a young person lacks experience, since some length of time is needed to produce it. Indeed to understand the difficulty and importance of experience we might consider why a child can become accomplished in mathematics, but not in wisdom or natural science. Surely it is because mathematical objects are reached through abstraction, whereas in these other cases the principles are reached from experience. ${ }^{16}$

[C] It is... [evident] that [phronessis] is not scientific-knowledge; for, as we said, it concerns the last thing i.e., the particular, since this is what is achievable in action. [D] Hence it is opposite to [nous]. For [nous] is about the first terms, those that have no account of them; but [phronessis] is about the last thing, an object of perception [aisthēsis] not of scientific knowledge. [E] This is not the perception of special objects, but the sort by which we perceive that the last among mathematical objects is a triangle; for it will stop there too. This is another species [eidos] of perception than perception of special objects; but it is still perception more than [practical-wisdom] is.

The major points in this passage — divided above into sections [A]-[E] — are the following: first, the difference among phronēsis, epistème, and, nous defined in terms of their

\footnotetext{
${ }^{15}$ Instead of 'prudence' I use 'practical wisdom' for phronēsis and 'intelligence' rather than 'understanding' for nous.

${ }^{16}$ I do not address Baracchi's remarks about [B]: the relation between sophia and phusis, and "awareness" of sophia's limitations, pp. 198-203. Also, I intentionally omit lines a19-21: elaboration on the same point, and a2124: "deliberation may be in error about either the universal or the particular" (cf. 1139a5-15, 1141a23-7). See Segvic (1990), pp. 144-171; Cooper (1975), Ch. 1.
} 
objects; furthermore, the relevance of experience's acquisition for both the practically wise person and the scientist in order to grasp the objects of their concern. Finally, the crucial distinction among sorts of perception, and how the objects of nous differ in kind from those that sensation and mere perception grasp. I suggest here that Aristotle refers to nous as a 'sort of perception' because it is analogous to mere perception in the sense that both cognitions do not involve logos and proof. Also, this 'sort of perception' would lead to a sort of knowing, say, empirical-knowledge versus scientific-knowledge, which does not require having demonstrative structure.

At[A] Aristotle brings back a puzzle discussed in VI.7 about the requirements of phronēsis, where he claims that since it is concerned with action, its objects known (gnōrimos) are both the universal (katholou) and the particular (kath'hekaston) - which is confirmed here [A"]. Since phronēsis is concerned with action, Aristotle emphasizes that it "must possess... the particular knowledge... more than the universal" (1141b22-3). Part of the problem is that phronesis, while possessing knowledge of universals, does not possess scientific-knowledge (episteme $\bar{e}$ ——which is confirmed here at $[\mathrm{C}]$ - , but rather another sort that has to do with knowing how to act correctly, and knowing that living well is the highest goal. Hence, in this discussion it is necessary to understand that the notion of the aforementioned 'universals' do not entail a necessary law-like relation in a strict sense, but are usually true (hōs epi to polu), e.g., judgments, beliefs, and practical advice (Irwin, 1999, p. 352), which is probable that they almost always hold (cf. 1143b12-4).

Since Aristotle distinguishes between the objects of phronēsis and epistemēe at [C], it is convenient to consider that universals can be tentatively determined as: 'always true'; e.g., in mathematics; 'for the most part' true, e.g., in physics; or 'usually' true, e.g., in ethics: a reputed belief (endoxa) (1139b8-9, b20-35; 1140b1-31). Let us call the latter ethical-universals because they are part of the objects that phronēsis is concerned with, or quasi-universals, because they are not universals as in the rigid content of epistèmé.

The specification of another kind of objects is important here [A"] and at $[\mathrm{C}]$. According to Aristotle, phronēsis is concerned with 'particulars.' He primarily alludes to particular situations or actions, i.e., particular actions that promote the end, or actions of "determinate types" undertaken in order to achieve the best good (Irwin, 1999, pp. 245; 341). ${ }^{17}$ Let us consider that when Aristotle says that phronēsis has particular knowledge more than 'the universal,' he may suggest more familiarity with particular actions, i.e., being habituated to specific type of actions or having more efficacy in concrete actions whose specific type has been repeatedly practiced by an agent (Vasiliou 2007, p. 75). Aristotle seems to imply here that knowledge of particulars is knowledge gained by experience, e.g., the practice of the same type of actions a person performs, which enables her to apply her knowledge of the quasi-universal to particular circumstances or situations. ${ }^{18}$ Notice that this point alludes to Aristotle's emphasis on acquiring experience for distinguishing particular things at [A"]. Specifically, he illustrates it in VI.7: probably a person who knows "which sorts of meats are light" will be more successful and

${ }^{17}$ Irwin (1999) distinguishes "determinate types"- - e.g., 'bird meats' as opposed to 'light meats' — rather than "particular instances" or "individuals"- e.g., this piece of chicken (p. 245). Cooper (1975) highlights "types of situations" (pp. 22, 28-30).

${ }^{18}$ Segvic (1995) observes: the person that possesses phronēsis is "like the rest of us in that his conception of the good life is largely embodied in his dispositions to view particular situations, and respond to them, in certain ways" (p. 159). 
be healthier than the person who only knows the general principle, i.e., "that lights meats are digestible and hence healthy" (1141b20-2). ${ }^{19}$

In the framework of Aristotle's distinction between objects, it is central to consider the role that experience plays. Accordingly, the person acquires knowledge of particulars through constant practice with diverse type of actions, and so she gains the experience necessary to achieve her end, which evidently requires time. This is why it is not possible to be a young practically wise person [A']: while young people can acquire theoretical knowledge, e.g., to get the axioms and rules of geometry or mathematics, to be a practically wise person requires experience and time. Yet, it is possible that these elements, however, are merely necessary but not sufficient conditions; experience and time by themselves do not guarantee the result.

To expand: since knowledge of particulars is derived from experience, Aristotle may also believe that a young person would be able to get an ethical-universal, in a way relatively parallel to how a young person would learn a mathematical definition [A', B], without yet having gained the experience necessary for responding to particular situations or for performing ethical actions in circumstances of her life.

In support of this account, in [B] Aristotle attempts to show the scope of experience and sheds light on the sort of objects that the scientist and the wise person can access through experience. The contrast with mathematical objects is evident again: even the inexperienced person can get access to those objects through abstraction. Further, Aristotle offers an important claim: experience is relevant not only for the practical wise person in order to get to know particulars, but also for the scientist and wise person (sophos) in order to grasp the first principles (archai). What is important to realize at this point is that in order to reach first principles induction is necessary-Aristotle maintains this thesis at section [G] of the second passage relevant to our discussion (see also 1139b30-2).

The fact that, at [C], Aristotle distinguishes between phronēsis and epistēmē in terms of the objects known by the former, suggests that some of phronessis' objects are particulars, and phronessis has more knowledge of them than ethical-universals or quasi-universals. Phronessis is not scientific-knowledge because it is concerned with the apprehension of the 'last thing,' the term refers to those things that are reached last as one proceeds "from the more general or universal to the more particular" (Irwin 1999, p. 247). That is, Aristotle identifies particulars as "last things" by reference to both (1) the demonstrative structure of scientific-knowledge, namely, the deductive method which goes from universals towards explaining the conclusion, and (2) the objects of its concern that not only are necessary, but also come to be from necessity, and so they are first (cf. 1139b20-35). Consequently, in this context 'the last' thing alludes to the particular that (a) "comes last (eschaton) in the process of deliberation" (Rowe, 2002; cf. Irwin, 1999), (b) "the thing to be done [which] is an ultimate particular thing" (Rackham, 1934) or (c) "the decision and... the situational particulars as they appear under final analysis" (Broadie, 2002). At this point, it is important to remark that in our second relevant passage (see sections $[\mathrm{F}]-[\mathrm{G}])$ Aristotle also alludes to 'the last.'

In [D] we learn that nous has as its objects the 'first terms' or concepts (horoi). Let us preserve Aristotle's reference to them as principles (archai) stated at (1140b31-2), conceived as 'the most universal.' Accordingly, nous has as its object the first principle of which there is no logos, i.e., no linguistic explanation or proof of the argument. In other words, nous does not give "reasons" or explanations, and neither does it offer proof of the argument or provide further

${ }^{19}$ See Cooper (1975), pp. 30-1. Cf. Met 981a24-30 for the difference between know that vs. know why; See also Vasiliou (2007) §6. 
demonstration. Aristotle may imply here that having an account of $p$ is to be able to provide a deductive argument for $p$, which is a characteristic of epistèmé. However, since epistèmé cannot get access to principles, nous is the state whereby it is possible to know principles (cf. $N E$ 1140b33-6, 1141a8-9; see also my fn. 6 for clarification on this point). ${ }^{20}$

In order to provide more emphasis on the distinction between phronessis and epistème, Aristotle offers an additional point: some objects of phronēsis, 'last things' or particulars, are grasped by perception (aisthēsis), as opposed to the objects of epistēmē. Here, Aristotle indicates an important distinction between knowledge of universals and perception of particulars, as we will see when we turn to §III. Although Aristotle considers that the last thing is an object of perception, it is not definitive that the objects of phronessis are perceived-nonetheless, contingent things or individual objects, rather than actions, are always perceived. This specific point seems to be the reason why, at [E], Aristotle posits a useful distinction and sheds light on the account of aisthēsis. He rules out here that the perception of the specific objects of phronēsis is that whereby our five senses apprehend "special objects." In order to account for that perception, he mentions that it is similar to that which grasps objects like geometrical figures. Nevertheless, it is still another sort (eidos) of perception, which is after all closer to perception than practical reasoning.

Here eidos comprises a form that is distinct from mere perception because it grasps objects of a specific sort, and thus, this may involve a kind of cognition whereby 'what is achievable in action' is apprehensible. But why does Aristotle use a 'sort of perception'? One suggestion is that Aristotle may intend to show that the cognitive faculty that apprehends those objects is analogous to mere perception because it is likely that both cognitions do not involve logos and proof; in this sense, it could be like perception (see AnPo 92b3-4). On the other hand, Aristotle may show that this sort of perception would lead to a sort of knowing, say, empiricalknowledge versus scientific-knowledge, which of course would not require having demonstrative structure. If I am correct, this would satisfy [C] and [D], and it would anticipate our second passage, i.e., sections $[\mathrm{F}]$ and $[\mathrm{G}]$. After all, Aristotle may want to restrict the function of suchrelatively - undefined cognition, again, based on the discrimination of its specific sort of objects, and on the aforementioned two suggestions.

With these two preliminary suggestions, we can now fill in the details of how Aristotle considers nous to be a different capacity than sensation and mere perception, and one through which particulars and indemonstrable principles become intelligible.

Irwin observes that at [E] Aristotle provides three ways of considering 'perception' in this context (pp. 247; 341-2). I elaborate somewhat on them to determine their strict differences.

First, let us call sensation the grasp relative to our senses or sensory modalities: sight, hearing, smelling, tasting, and touching, whose "special objects" are, respectively, colors, sounds, smells, flavors, and textures. If we accept that in other works Aristotle illustrates that our senses have their own distinctive objects for discrimination (AnPo 99b36), and he provides examples: colors for sight, sounds for hearing, etc. (DA, 418a11-16; 434b9-435a10), we might say that sensation has qualitative character in virtue of which one is able to sense, e.g., the distinctive pitch of a violin.

${ }^{20}$ There are not proofs of principles (AnPo 100b5-12, 76a31, 92a34-b4). Some principles can be deduced from others; however, not all principles are demonstrable. When the premises are scientifically-known, they are deduced; this process either continues or comes to a stop at a certain point. When premises come to a stop they are indemonstrable, and there is no epistēme (see my fn. 6). 
Second, let us call mere perception the grasp relative to the apprehension of figures such as the basic polygon with three vertices or "the triangle." Accordingly, one is able to have the common sense that it is "the simplest mathematical figure" (Irwin, 1999), or "the last element" (Rowe, 2002). By 'last' here Aristotle may mean that the "triangle is the last form into which a rectilinear figure can be divided: two straight lines cannot enclose a space" (Rackham, 1934); in this sense, it would be the simplest too. Next, Aristotle adds: "for it will stop there too." This suggests that perceiving that the triangle as the simplest figure does not demand an ulterior demonstration or proof. Hence, 'the triangle' is "grasped by inference from the senses, but not by the senses themselves" (Irwin, 1988, p. 316). ${ }^{21}$ From this, we might infer that perception, as opposed to sensation, has a content that conceptualizes whatever thing that enables us to sense. Thus, perception would involve qualitative character and intentional content, e.g., I see that the simplest geometrical figure is a triangle.

Finally, let us call discernment the grasp relative to phronēsis' process of deliberation whereby premises about action or particular actions become intelligible rather than sensed or merely perceived. Discernment or this sort of perception might involve, although not necessarily, qualitative character, but it definitely involves intentional content plus a mental attitude with regards to endoxa. For example, based on an endoxa that $p$, I have the belief that $p$, then by practicing $p_{a}, p_{b}$, and $p_{c}$ actions I am able to discern $p_{b}$ actions as better options than $p_{a}$ and $p_{c}$ in order to achieve my end about $p .^{22}$ In other words, this sort of perception allows us to discern similarities and differences among, in the first instance, a series of $p$ actions and, derivatively from that, the corresponding endoxa that $p$. This sort of perception turns out to be nous, as it will be shown next, which is the intelligence necessary to determine particular features in a given situation. ${ }^{23}$

\section{NE: VI.11, 1143a33-b12}

The central points of the second passage relevant to our discussion-here divided below into sections $[\mathrm{F}]-[\mathrm{G}]$ — are as follows: the analysis of nous, which grasps first principles and particulars, the plausibility that nous is the cognitive faculty or sort of perception mentioned at [E], and the claim that the inductive method is suitable for nous. By examining this passage, I show why Baracchi's interpretation that Aristotle suggests "the conjunction, if not the simple identity, of nous and aisthēsis" ends up being unsatisfactory.

Aristotle opens the discussion by insisting that "all the things achievable in action are particular and last things." He then writes:

$[\mathrm{F}][$ Nous] is also concerned with the last things, and in both directions. [F'] For there is [nous], not a rational account $[\operatorname{logos}]$, both about the first terms and about the last. [F] In demonstrations [nous] is about the unchanging terms that are first. In premises about action [nous] is about the last term, the one that admits of being otherwise, and hence about the minor premise. [G] For these last terms are

\footnotetext{
${ }^{21}$ Seeing "the son of Cleon" entails a "coincidental perception" that results from perceiving the perceptible qualities of the object (DA 424a24-425a30).

${ }^{22}$ I have the mental attitude independently of its utterance: "I believe that $p_{b}$ actions will lead me to achieve my end about $p . "$

${ }^{23}$ The intelligent agent is not excluded from sensing or perceiving, but "the good action... depend[s] on the well-functioning of rational thought and desire as such" (Broadie, 2002, p. 362).
} 
beginning of the end to be aimed at, since universals are reached from particulars. We must, therefore, have perception of these particulars, and this [sort of] perception is [nous]. That is why [nous] is both beginning and end; for demonstrations begin from these things and are about them. ${ }^{24}$

At this point, we are in a position to see the parallel points of the two passages. At [D] Aristotle says that nous is concerned with 'first terms' or principles; now, in [F] he claims that nous is able to grasp 'last things' too, 'and in both directions.' Aristotle contrasts nous with phronēsis in terms of their objects of concern at [D], and phronessis with epistèmé not only in terms of their respective objects of concern, but also their respective methods at [A][C]. At [D] Aristotle specifies that nous does not offer an account of the first terms; ${ }^{25}$ now in [F'], he claims that nous is also concerned with the 'last' thing of which there is also no logos. The meaning of 'last things' is already settled at [C]-[D]. However, what does Aristotle mean exactly by 'in both directions'? Aristotle indicates that nous is the capacity of grasping both kinds of objects: universals that concern epistème and particulars that concern phronēsis, without implying that nous proceeds either by demonstrative knowledge or by practical reasoning. Nous makes intelligible the truth of the first principles and also discerns what to do in particular situations; in this sense, nous is a sort of perception at [G], cf. [E]. The central point here is that both the first principle and the last thing become intelligible through nous without logos, i.e., no explanatory causal factor is given for grasping them.

\section{Baracchi writes,}

Nous is of both, and the distinction between nous as perceiving definitions and nous as perceiving singularities is only perspectival: seen from the operation of demonstration, nous provides the principle, the universal; seen from the operation of practical deliberation, nous provides the perception of the circumstances to be assessed. Here we come to appreciate the twofold nature of nous, as intellectual stricto sensu and intuitive or, in fact, sensible. In both cases, nous names... an intellectual-sensible grounding [where] there is no discursive knowledge, no logos.

Aristotle here is not proposing a dichotomy of 'practical nous' and 'theoretical nous,' as it were, so much so that he emphasizes the fundamental role of particulars in the formulation of universals, and, hence, the implication of sensation in intellectual perception. Indeed, because of this he intimates the conjunction, if not the simple identity, of nous and aisthesis - a conjunction that it will be hard to write off as solely applying to some subdivision of nous that would concern practical matters alone. (pp. 195-6)

Several difficulties arise here. First, Baracchi surprisingly overlooks passage [E] in which Aristotle distinguishes among sensation, mere perception, and a sort of perception. Missing this distinction, she considers nous as perception (aisthēsis) and not — or not only_as intelligence. More strikingly, perhaps, is that her comments disregard the fact that perception is only of particulars and not of universals. Aristotle suggests this at [D]. He confirms the point at [G] and in AnPo: "for of particulars there is perception; for it is not possible to get [epistemē] of them" (81b6-7) and "[I]t is impossible to perceive what is universal," "for one necessarily

\footnotetext{
${ }^{24}$ I intentionally omit lines b6-14: nous and other capacities require experience, and line b15: see $\S \mathrm{I}$. Concerning experience and its cognitive value in Aristotle see Frede (1990) p. 225-50.

${ }^{25}$ Here nous is distinguished, indirectly, from epistēme too.
} 
perceives particulars, whereas [epistēmē] comes by becoming familiar with the universal" (87b32-88a 11).

Baracchi might object that she takes into account Aristotle's claim that "perception is of the universal" in AnPo 100a15-100b5. However, if we examine that complex passage, it becomes clear that Aristotle refers rather to gaining access to universals from particulars by induction, or simply "that concept acquisition proceeds from the less to the more general" (Barnes, 1975, p. 256). In other words, Aristotle shows that principles become known or intelligible by experience; he does not show that universals per se are perceived. Thus, it is reasonable to presume that Baracchi either neglects or misinterprets this point.

Moreover, we may wonder whether this is merely a semantic problem. Since Baracchi understands that nous is the capacity to grasp both universals and particulars, and since universals are grasped from particulars by induction, she might consider it plausible to say that universals are perceived. However, even though she may add that 'nous [intellectually] perceives definitions,' it seems that the issue is not merely a semantic one. Instead, Baracchi uses 'perceiving definitions' because she firmly believes that "the perception of principles is of incalculable consequence" (p. 29), and so she embraces a conjunction of nous and aisthessis, which is an unconvincing reading of Aristotle's project.

It should be clear by now that Aristotle unquestionably values perception highly as a source of knowledge. He also relies on it as a source of empirical inquiry (AnPo B.19; Met A.I). However, if we follow Baracchi's account, it would be incorrect to equate nous with one of its sources. For instance, Aristotle clearly accounts for a difference in kind by referring to two cognitive states: e.g., nous and epistēmē. Although nous is the principle of epistemēe, nous cannot be epistème (AnPo 72b23-25, 88b36, 100b15). ${ }^{26}$ So there is no reason to consider a conjunction of nous and aisthēsis. In fact, the ability to grasp an object $p$ by sensing or perceiving it is different than - and prior to - the ability that involves experience and familiarity with that object. Also, these abilities are different than nous, or our capacity for conceptual thought that is involved in grasping intellectually specific objects.

Furthermore, Baracchi's claim that 'the distinction between nous as perceiving... [universals] and nous as perceiving... [particulars] is only perspectival' is unconvincing. On the contrary, Aristotle's distinction is fundamental; for one thing, universals and particulars are different objects (see NE 1139a7-9; 1139b23-4; 1140b30-5), ${ }^{27}$ but more importantly the methods by which epistēmē and phronēsis proceed in grasping their respective objects are different. One proceeds by deduction, while the other proceeds by induction. Aristotle refers to these two methods when he mentions that nous is 'in both directions.' These methods display the cognitive objects with which nous is concerned, though this does not mean that nous proceeds by demonstration.

On the other hand, Baracchi's conception that nous has a 'twofold nature,' is not consistent with the fact that nous makes intelligible the particular and the universal (in) both (directions). There is no evidence that nous constitutes a dual nature, as she supposes. The only

${ }^{26}$ Additional examples: AnPo 90b18-91a11. However, it is possible that Aristotle can consider nous as a sort of epistēmē in AnPo A.2, and A.3 (see my fn. 6.), as he considers nous as a sort of perception in NE without entailing an identity.

In DA III.3, Aristotle says that the identification of noein with aisthēsis, suggested by Empedocles, should be rejected. Regarding the problematic analogy between noein and aisthanesthai see also DA III.4, 429a29-b13, and DA III.7, 431a8-b19.

${ }^{27}$ A universal is what is common to many particulars. As universals are instantiated, they can be considered to be attached to many particulars. See Met 981a20, 1038b1-10; AnPo 85a30; cf. Irwin, 1988, Ch. 4 §42. 
special intellectual excellence that entails a dual nature for which there is evidence is phronēsis, which involves both intellectual and practical capacities. The conception of a twofold nature of nous goes hand in hand with Baracchi's conceptions of unity, identity, etc., of nous and aesthesis, which is untenable, as we will see when we turn to section [G].

Lastly, even though in the final sentence of Baracchi's quotation above she recognizes a relation of non-discursive knowledge with logos, the fact that there is nous but 'not logos' is interpreted by her as a limit of "thinking"-here [F'] and by reference to [D] as well: "Nous pertains to the domain enclosed within the extremes of particularity, on the one hand, and definitions, on the other... [which] bound and delimit the space of thinking." (p. 195). It is unlikely that Aristotle classifies nous as a virtue of thought, and simultaneously limits its function in thinking. Instead, it is more plausible to hold that nous proceeds by thoughts even though it does not involve a linguistic explanation of the first terms and last things. Thus, being without logos does not weaken its rational capacity, strictly speaking, nor does it delimit or limit 'the space of thinking.' It only shows that nous does not proceed by demonstration or that nous is a non-discursive cognitive faculty.

In the remaining part of this paper, I hope to elucidate what Aristotle means by saying at [G] that 'nous is both beginning and end.' Baracchi writes, the fact "[ $\mathrm{t}$ ] hat nous should be 'both a beginning and an end' corroborates the unity of nous as a matter of both intellectual and sensible perception" (p. 196). Again, Baracchi's thesis seems unconvincing. First, Aristotle's statement does not seem to 'corroborate' any 'unity of nous as a matter of both intellectual and sensible perception.' Rather, Aristotle suggests that nous gets intellectual access to first principles by induction. Since universals are reached from particulars, or so-called 'last things,' these are considered the beginning of the inductive process, which of course are also the end when these are considered with reference to the deductive method: from universals to particulars, cf. [D].

Baracchi comments further: "[N]ous presides over the 'inductive synthesis' originally connecting particulars and universals," and hence, Aristotle "intimates the conjunction, if not the simple the identity, of nous and aisthēsis" (pp. 194-6). Aristotle certainly points out that the universals are grasped inductively, and by exercising intelligence it is possible to discern "the relevant features of particular situations, so that general principles can be applied to them" (Irwin, 1999, p. 250), or, similarly, that an endoxa can be confirmed through particulars. In other words, by constant exercise of particular experiences, say actions $p_{a}, p_{b}$, and $p_{c}$, it is possible to make them intelligible, and it is possible to obtain a 'general principle' $p$. Yet perceiving is of particulars and not of the universal. While perception forms part of the process of induction, acquisition of the universal is the result of repeated instances of $p$ type (AnPo 88a3-14), i.e., "we do not strictly speaking realize that some connection holds universally in the simple act of perception itself" (Lesher, 1973, p. 53).

Finally, on my understanding, by saying that 'nous is both beginning and end,' Aristotle claims that the cognitive faculty is defined in terms of its objects. He says at [F] that 'last terms are beginning of the end to be aimed at,' since these objects are grasped by nous. Instead of an 'identity of nous and aisthesis,' Aristotle introduces at [E] a sort of perception, which is recognized as intelligence here, and it is determined in terms of its objects. ${ }^{28}$ If the objects of nous were the same as those of sensation, or mere perception, or if nous and aisthēsis comprise an identity, nous would not be both beginning and end in the sense that Aristotle posits. Nous

${ }^{28}$ On the distinction between activities of the thought from activities of the perception, see $N E$ 1175a27-8. Perception and thought are determined by its suitable objects, see $D A 415 \mathrm{a} 15-25$; 418a20-5. 
would only grasp particulars: since there is no sensation or perception of first principles. Principles are grasped through nous by induction, and nous or intelligence seems to be selfsufficient in grasping its objects, just as sensation and perception grasp their corresponding sorts of objects.

\section{Conclusion}

By examining two key passages of Book VI, I have shown that Aristotle does not equate nous and aisthèsis in any sense. Baracchi's argument to the contrary is unsuccessful. Even though Aristotle identifies nous as a sort of perception, it is considered a different capacity from sensation and the ordinary perception by which particulars and indemonstrable principles become intelligible. Nous or intelligence is an independent cognitive faculty that does not require perception for grasping its objects. While Aristotle emphasizes that experience is relevant in order to grasp particulars and that it is possible to grasp first principles by induction, he does not attempt to show that sensation and experience enjoy a higher status than episteme and nous. These processes are complementary for achieving knowledge. I hope to have shown significance of the fact that the differentiation among cognitive faculties is given as a function of their objects of apprehension. ${ }^{29}$

${ }^{29}$ I am grateful to Iakovos Vasiliou and Nick Pappas for valuable comments on an earlier version of this essay. I am also grateful to the referees of the Journal Méthexis for providing helpful comments that improved this paper. 


\section{References}

Baracchi, C. (2008). Aristotle's ethics as first philosophy. Cambridge: Cambridge University Press.

Barnes, J. (1975). Aristotle's Posterior Analytics. Oxford: Clarendon Press.

Barnes, J. (1995). Posterior Analytics. In Barnes, J. (Ed.), The complete works of Aristotle. Princeton: Princeton University Press.

Cooper, J. M. (1975). Reason and human good in Aristotle. Cambridge, Mass.: Harvard University Press.

Devereux, D. (1986). Particulars and universals in Aristotle's conception of practical knowledge. In Review of Metaphysics 39, 483-504.

Frede, M. (1990). "An empiricism view of knowledge: memorism.” In S. Everson (Ed.) Companions to ancient thought 1, Epistemology, (p. 225-50). Cambridge: Cambridge University Press.

Irwin, T. (1988). Aristotle's first principles. Oxford: Oxford University Press.

Irwin, T. (1999). Aristotle, Nicomachean Ethics. Indianapolis: Hackett Publishing.

Irwin, T. \& Fine, G. (1995). Aristotle: Selections. Indianapolis: Hackett Publishing.

Lesher, J. H. (1973). The meaning of nous in the Posterior Analytics. In Phronesis 18, 44-68.

Perelmuter, Z. (2010). Nous and two kinds of epistemē in Aristotle's Posterior Analytics. In Phronesis 55, 228-254.

Rackham, H. (1934). The Nicomachean Ethics. Cambridge, Mass.: Harvard University Press.

Reeve, C.D.C. (1992). Practices of reason. Oxford: Clarendon Press.

Reeve, C.D.C. (2006). Aristotle's on the virtues of thought. In R. Kraut (Ed.), The Blackwell guide to Aristotle (pp. 198-217). Malden, MA: Blackwell Publishing.

Rorty, O. A. (1980). The place of contemplation in Aristotle's Nicomachean Ethics. In A. Rorty (Ed.), Essays on Aristotle's Ethics, (pp. 377-394). Berkeley: University of California Press.

Ross, W. D. (1995). Metaphysics. In Barnes, J. (Ed.), The complete works of Aristotle. Princeton: Princeton University Press.

Rowe, C. and Broadie, S. (2002). Aristotle, Nicomachean Ethics. New York: Oxford University Press.

Segvic, H. (2009). Deliberation and choice in Aristotle. In M. Burnyeat (Ed.), From Protagoras to Aristotle, (pp. 144-171). Princeton: Princeton University Press.

Vasiliou, I. (2007). Virtue and argument in Aristotle's ethics. In Moral Psychology: Poznan Studies in the Philosophy of the Sciences and Humanities, vol. 94: 37-76. New York: Rodopi. 